\title{
Parathyroidectomy Results in Primary Hyperparathyroidism: Analysis of the Results From a Single Center
}

\author{
Mehmet Taner Unlu, ${ }^{1}$ () Nurcihan Aygun, ${ }^{2}$ (I) Ismail Ethem Akgun, ${ }^{2}$ (i) Sitki Gurkan Yetkin, ${ }^{2}$ \\ (1) Rumeysa Selvinaz Erol, ${ }^{3}$ (1) Adnan Isgor, ${ }^{4}$ (1) Mehmet Uludag ${ }^{2}$
}

'Department of General Surgery, Basaksehir Cam and Sakura City Hospital, Istanbul, Turkey

${ }^{2}$ Department of General Surgery, University of Health Sciences Turkey, Sisli Hamidiye Etfal Teaching and Research Hospital, Istanbul, Turkey ${ }^{3}$ Division of Endocrinology and Metabolism, Department of Internal Medicine, University of Health Sciences Turkey, Sisli Hamidiye Etfal

Teaching and Research Hospital, Istanbul, Turkey

${ }^{4}$ Department of General Surgery, Bahcesehir University Faculty of Medicine, Istanbul, Turkey

\begin{abstract}
Objectives: The curative treatment of primary hyperparathyroidism (PHPT) is surgery. Persistent and recurrent disease may develop after surgical treatment. In this study, we aimed to evaluate the surgical cure rate in patients who underwent surgery for PHPT in our clinic.

Methods: The data of patients who underwent parathyroidectomy for PHPT by two experienced surgeons between 2000 and 2015 in our clinic were retrospectively evaluated. Patients who were followed for at least 6 months after their first parathyroidectomy were included in the study. Surgical cure and persistent and recurrent disease rates were evaluated in patients.

Results: During this period, 368 interventions were performed in 357 patients ( $293 \mathrm{~F}$ and $64 \mathrm{M}$ ) who were operated for PHPT in our clinic, with a mean age of $54.9 \pm 13.1$ years. In the first surgery, 116 patients (32.5\%) had bilateral neck exploration, 251 patients (67.5\%) had unilateral neck exploration (UNE) or focused parathyroid surgery (FPS). In the first operation, 343 patients (96.1\%) had cure, 14 patients ( $13 \mathrm{~F}$ and $1 \mathrm{M}$ ) remained persistent. Secondary surgical intervention was performed in 11 patients. UNE or FPS was performed to 10 patients (90.9\%); partial sternotomy was performed to one patient. Ten of the patients had cure. Three of these patients had a solitary parathyroid adenoma that was not removed in the first surgery, and seven patients had a second adenoma. Four patients remained persistent (1.1\%). Recurrent disease developed in four patients during follow-up (1.1\%). Total cure rate was $97.8 \%$. Conclusion: The only definitive treatment for PHPT is surgery. High surgical cure can be achieved by pre-operative evaluation and appropriate surgical planning. However, persistent PHPT may develop, especially due to double adenoma or ectopic location. Patients with persistent PHPT can be evaluated with repeat imaging methods and with appropriate surgical planning, a high cure rate can be obtained in secondary surgery, which can increase the total surgical cure rate. Recurrence rate is rare.
\end{abstract}

Keywords: Hyperparathyroidism; parathyroidectomy; persistent disease; recurrent disease.

Please cite this article as "Unlu MT, Aygun N, Akgun IE, Yetkin SG, Erol RS, Isgor A, et al. Parathyroidectomy Results in Primary Hyperparathyroidism: Analysis of the Results From a Single Center. Med Bull Sisli Etfal Hosp 2021;55(2):173-178".

$P^{\prime}$ rimary hyperparathyroidism (PHPT) is a common endocrine disorder characterized by an increase in calcium (Ca) and parathyroid hormone (PTH) or an increase in one of these, as a result of impaired regulation of serum calcium regulation due to excessive PTH production by gaining inappropriate autonomy of one or more parathyroid glands. ${ }^{[1]}$ PHPT is the third most common endocrine disorder after diabetes mellitus and thyroid diseases. ${ }^{[2]}$

Address for correspondence: Mehmet Taner Unlu, MD. Basaksehir Cam ve Sakura Sehir Hastanesi, Genel Cerrahi Klinigi, Istanbul, Turkey Phone: +90 5392113236 E-mail: m.taner.unlu@gmail.com

Submitted Date: March 30, 2021 Accepted Date: April 14, 2021 Available Online Date: July 02, 2021

${ }^{\circ}$ Copyright 2021 by The Medical Bulletin of Sisli Etfal Hospital - Available online at www.sislietfaltip.org

OPEN ACCESS This is an open access article under the CC BY-NC license (http://creativecommons.org/licenses/by-nc/4.0/) 
The only definitive treatment for PHPT is surgery. Surgical intervention is recommended for all symptomatic patients and asymptomatic patients under 50 years of age, who meet certain criteria; however, since the only definitive treatment of PHPT is surgery, surgical treatment should be considered in all patients for whom surgery is not contraindicated. ${ }^{[3]}$

Although the traditional surgical treatment method in PHPT is bilateral neck exploration (BNE), focused parathyroid surgery (FPS) or unilateral neck exploration (UNE) methods have become the first choice in selected patients thanks to the advances in technology and imaging methods. With these methods, the same success rates can be achieved with less dissection and less complication rates compared to BNE. ${ }^{[4-6]}$

Some conditions are important in determining the surgical strategy following the operation indication. In this process, pre-operative localization possibilities, whether there are risk factors for multiple gland disease in the patient, and the facilities of the surgical center, such as peroperative frozen or rapid serum parathormone testing, should be considered. ${ }^{[7,8]}$ High cure rate can be achieved in the first surgery by minimizing the risk of complications in PHPT surgery. ${ }^{[9-12]}$ However, secondary surgical procedures may be required with the diagnosis of persistent or recurrent PHPT after parathyroid surgery, even in centers experienced in endocrine surgery. ${ }^{[13,14]}$ In the first surgical intervention for PHPT in experienced centers, the cure rate is over $95 \%$. However, despite the developments and innovations in pre-operative localization studies and all developments in biochemical methods, it has been reported that the rate of persistent and/or recurrent PHPT is up to $30 \%$ in some series. ${ }^{[15]}$

Persistent primary hyperparathyroidism ( $p$-PHPT) is the condition of increased serum calcium and PTH within the first 6 months postoperatively, and recurrent primary hyperparathyroidism ( $r$-PHPT) is the emergence of hypercalcemia and PTH elevation 6 months after post-operative normocalcemia is achieved..$^{[9]}$ p-PHPT disease is usually related to parathyroid gland pathology that is present in the first surgery, which is not removed, and is related to failure in surgery. r-PHPT, on the other hand, is generally related to the newly developing parathyroid gland pathology. ${ }^{[13,14]}$ The vast majority of cases requiring reexploration are due to $\mathrm{p}$-PHPT. The most common reason for reexploration in p-PHPT is the inexperience of the surgical team in terms of localization and adequate resection. $[13,14,16]$ In the literature, persistent hyperparathyroidism is reported as $2-22 \%$ and recurrent hyperparathyroidism is reported as $1-10 \%$ in PHPT. ${ }^{[9,14,17-23]}$

In secondary surgical procedures performed for persistent and recurrent PHPT, the risk of complications may be higher and the cure rate may be lower than the first

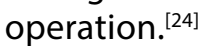

In this study, we aimed to evaluate the surgical cure rate in patients who underwent surgery for PHPT in our clinic.

\section{Methods}

The data of patients who were operated by two experienced endocrine surgeons ( $\mathrm{Al}$ and $\mathrm{MU}$ ) with the diagnosis of PHPT between 2000 and 2015 were retrospectively evaluated. For our study, research permission was obtained from the local ethics committee on March 30, 2021, numbered 1822. Preoperative laboratory tests, imaging methods, intraoperative findings, and post-operative pathological results and postoperative biochemical results of the patients were evaluated. All patients were biochemically evaluated and a diagnosis of PHPT was made by differential diagnosis. Pre-operative sestamibi (MIBI) scintigraphy and/or ultrasonography were performed in all patients. Scintigraphy was performed as planar $\mathrm{MIBI}$ or MIBI single-photon emission scintigraphy. Patients whose first parathyroid surgeries were performed in our clinic were included in the study to evaluate the surgical results of our clinic. Patients who were operated on for parathyroid cancer and who were referred to our clinic due to persistent or recurrent disease were excluded from the study. All symptomatic patients for whom surgery was not contraindicated and who accepted surgery, and patients with asymptomatic PHPT with surgical indication were operated. For the surgical indication of asymptomatic patients, the latest versions of the international working group's guidelines, which have been published in 1990 and then updated in 2002, 2008, and 2013, were taken into consideration. . $^{[25]}$

In bilateral exploration, both sides of the neck were explored with a standard Kocher cervical incision, all four parathyroid glands were explored, and enlarged gland or glands were removed. Three and a half (3.5) subtotal parathyroidectomy was performed in multiglandular hyperplasia. In FPS, a 2-3 cm incision was made from the anterior edge of the sternocleidomastoid muscle (SCM), extending from the lateral side between the anterior edge of the SCM and the lateral edge of the strep muscles only the enlarged gland was inspected and the other gland on the same side was not visualized. UNE was performed with a $2-3 \mathrm{~cm}$ lateral incision from the anterior edge of the SCM as in FPS or with a classic Kocher incision from the midline. The neck side to be explored was entered and the enlarged gland on only one side of the neck and the normal gland on the same side were explored. These two methods were defined as minimally invasive parathyroidectomy. ${ }^{[26,27]}$

Blood samples were taken from patients for parathormone measurement before excision, $10^{\text {th }}$ min after excision, and $20^{\text {th }}$ min after excision and were sent to the laboratory. However, we could not use parathormone measurement intraoperatively in our study because we could have these results after surgery.

FPS or UNE was applied to patients with positive two imaging methods, and UNE was applied to patients with a posi- 
Table 1. Pre-operative biochemical and imaging results of the patients

\begin{tabular}{lc}
\hline Characteristic & \\
\hline Age mean+SD/year (min-max) $(\mathrm{n}=357)$ & $54.9+13.1(20-83)$ \\
Gender & $293(82.1 \%)$ \\
Female & $64(17.9 \%)$ \\
Male & \\
Pre-operative results & $11.3+0.98(8.6-17)$ \\
Calcium (Ca) & $2.8+0.6(1.2-54)$ \\
Phosphorus & $2+0.3(1.4-2.4)$ \\
Magnesium & $0.8+0.3(0.4-1.8)$ \\
Creatinine & $31+11(16-74)$ \\
Urea & $112+65(29-431)$ \\
Alkaline phosphatase & $245+356(66-2610)$ \\
Parathyroid hormone & $18.5+14.7(4-68)$ \\
25(OH)VitD3 & $323+180(42-600)$ \\
24 h urine Ca & $318(89.1 \%)$ \\
Pre-operative imaging method & $339(89 \%)$ \\
USG & $306(81 \%)$ \\
Scintigraphy & \\
USG+Scint & \\
\hline
\end{tabular}

Min: Minimum; Max: Maximum; SD: Standard deviation; USG: Ultrasonography.

tive single imaging method. BNE was applied to patients in whom two imaging methods were negative or two were incompatible. In FPS or UNE, when no pathological glands were detected on the side where imaging method was positive, when two normal glands were seen, or in the presence of two enlarged glands, BNE was resumed. To resume with $B N E$, the lateral incision was extended from the midline to the other side and converted to a standard Kocher incision.

Recurrence of hypercalcemia in the first 6 months after surgery was defined as persistence and as recurrence after the $6^{\text {th }}$ month. Patients with at least 6 months follow-up were included in the study. Patients with a follow-up of $<6$ months and whose follow-up data and file could not be accessed were excluded from the study.

\section{Statistical Analysis}

Age and pre-operative biochemical values of the patients were given as mean $\pm \mathrm{SD}$ (min-max). Operation and cure rates were expressed in \%.

\section{Results}

During this period, data of 357 patients who met the criteria out of 402 patients who were operated for PHPT in our clinic were evaluated. Two hundred and ninety-three $(82.1 \%)$ of the patients were female, $64(17.9 \%)$ were male,
Table 2. Surgical results of patients BNE, UNE, and FPS

\begin{tabular}{lcc}
\hline Operations performed & $\mathbf{n}$ & $\%$ \\
\hline First operation & 116 & 32.5 \\
$\quad$ BNE & 251 & 67.5 \\
$\quad$ UNE or FPS & & \\
Second operation & 10 & 90.1 \\
$\quad$ UNE or FPS & 1 & 9.9 \\
$\quad$ Sternotomy & & \\
Persistent disease & 14 & 3.9 \\
$\quad$ Following first operation & 4 & 1.1 \\
$\quad$ Following second operation & 4 & 1.1 \\
Recurrent disease & 349 & 97.8 \\
Total cure & & \\
Pathology & 333 & 94.4 \\
$\quad$ Single adenoma & 10 & 2.8 \\
$\quad$ Double adenoma & 10 & 2.8 \\
\hline Hyperplasia & & \\
\hline BNE: Bilateral neck exploration; UNE: Unilateral neck exploration; FPS: \\
Focused parathyroid surgery.
\end{tabular}

and the mean age $( \pm S D)$ was $54.9+13.1$ (min: 20-max: 83). Pre-operative biochemical results and imaging methods of the patients are given in Table 1.

Three hundred and sixty-eight interventions were performed on these 357 patients. In the first operation, $116 \mathrm{pa}-$ tients (32.5\%) had BNE, 251 patients (67.5\%) had UNE or FPS. In the first operation, 343 patients $(96.1 \%)$ had cure, 14 patients (13 F and $1 \mathrm{M})(3.9 \%)$ remained persistent (Table 2). Persistent disease has become in 10 patients (4\%) who underwent UNE or FPS and in 4 patients (4\%) who underwent $B N E$, there is no significant difference between these procedures $(p=0.803)$. Reimaging methods were applied to all patients and surgical intervention was performed in 10 of 11 patients with positive imaging and in one of three patients with negative imaging. The second operation was performed in the early period (within the first 10 days of post-operative period) in six patients and in the late period (after 3 months postoperatively) in five patients. UNE or FPS was applied to 10 patients (90.1\%), one patient underwent sternotomy for mediastinal supernumerary parathyroid adenoma. Cure was achieved in $10(90.1 \%)$ of the patients. Of these three patients, two had ectopic and one had parathyroid adenoma that was not removed on the opposite side of the first surgery. In seven patients, the cause of persistent disease was secondary adenoma, the second adenoma was on the same side in three patients (two orthotopic and one ectopic), and in four patients, it was on the opposite side (three orthotopic and one ectopic), compared to the first removed adenoma (Table 3). 
Table 3. Results of patients with persistent disease after the first surgery BNE, UNE, and FPS

\begin{tabular}{|c|c|c|c|c|c|}
\hline $\begin{array}{l}\text { Patient } \\
\text { no. }\end{array}$ & $\begin{array}{l}\text { Age, } \\
\text { gender }\end{array}$ & $\begin{array}{l}\text { First } \\
\text { op. }\end{array}$ & Persistence reason & Secondary op. & Persistence reason \\
\hline 1. & $50 \mathrm{y}, \mathrm{F}$ & BNE & $\begin{array}{c}\text { Mediastinal supernumerary } \\
\text { adenoma }\end{array}$ & $\begin{array}{l}\text { Parathyroidectomy } \\
\text { with partial sternotomy }\end{array}$ & Mediastinal ectopic PT adenoma \\
\hline 2. & $44 y, F$ & FPS & $\begin{array}{l}\text { False-positive frozen in the first op, } \\
\text { PT not removed }\end{array}$ & & Ectopic intrathymic PT adenoma \\
\hline 3. & 53 y, F & BNE & Second adenoma & FPS & $\begin{array}{l}\text { Ectopic (in the carotid sheath) } 2^{\text {nd }} \\
\text { adenoma on the opposite side }\end{array}$ \\
\hline 4. & $60 y, M$ & UNE & Second adenoma & UNE & $\begin{array}{l}\text { Orthotopic } 2^{\text {nd }} \text { adenoma on the } \\
\text { opposite side }\end{array}$ \\
\hline 5. & $45 y, K$ & UNE & $\begin{array}{l}\text { False-positive scintigraphy and } \\
\text { frozen examination due to follicular } \\
\text { cancer }\end{array}$ & UNE & $\begin{array}{l}\text { Orthotopic PT adenoma on the } \\
\text { opposite side }\end{array}$ \\
\hline 6. & $46 y, F$ & UNE & Second adenoma & UNE & $\begin{array}{l}\text { Orthotopic } 2^{\text {nd }} \text { adenoma on the } \\
\text { same side }\end{array}$ \\
\hline 7. & $72 y, F$ & FPS & Second adenoma & FPS & $\begin{array}{l}\text { Ectopic (intrathymic) } 2^{\text {nd }} \text { adenoma } \\
\text { on the same side }\end{array}$ \\
\hline 8. & $59 y, F$ & FPS & Second adenoma & FPS & $\begin{array}{c}\text { Orthotopic } 2^{\text {nd }} \text { adenoma on the } \\
\text { opposite side }\end{array}$ \\
\hline 9. & $55 \mathrm{y}, \mathrm{F}$ & FPS & Second adenoma & FPS & $\begin{array}{l}\text { Orthotopic } 2^{\text {nd }} \text { adenoma on the } \\
\text { same side }\end{array}$ \\
\hline 10. & $77 y, F$ & FPS & Second adenoma & FPS & $\begin{array}{l}\text { Orthotopic } 2^{\text {nd }} \text { adenoma on the } \\
\text { opposite side }\end{array}$ \\
\hline 11. & $54 \mathrm{y}, \mathrm{F}$ & FPS & $\begin{array}{c}\text { Persistence after PT adenoma } \\
\text { excision }\end{array}$ & BNE & $\begin{array}{l}\text { No additional pathological glands } \\
\text { found }\end{array}$ \\
\hline 12. & $29 y, F$ & FPS & $\begin{array}{c}\text { False-positive frozen in the first op, } \\
\text { PT not removed }\end{array}$ & - & \\
\hline 13. & $65 y, F$ & BNE & No pathological glands found & - & Post-operative imaging is negative \\
\hline 14. & $69 y, F$ & BNE & No enlarged glands & - & Post-operative imaging is negative \\
\hline
\end{tabular}

BNE: Bilateral neck exploration; UNE: Unilateral neck exploration; FPS: Focused parathyroid surgery; op: Operation; y: Years; M: Male; F: Female.

Four patients remained persistent (1.1\%). In three of these, no pathological focus was detected in imaging; one patient had positive imaging and did not accept secondary surgery. Recurrent disease developed in four patients during follow-up (1.1\%). The total cure rate was $97.8 \%$ (Table 2 ).

\section{Discussion}

Surgical cure rate for PHPT is high in experienced centers, around $95-99 \% .{ }^{[4]}$ However, despite advances in parathyroid imaging and advances in surgical technique, persistent and recurrent diseases are the facts that challenge the surgical treatment of PHPT. Despite all the developments, p-PHPT and r-PHPT can be encountered, and these situations are particularly related to the non-recognition of multiple gland disease. ${ }^{[23]}$

In this study, we evaluated the data of patients who underwent their first surgical interventions for PHPT in our clinic. Surgical cure was provided in 343 (96.1\%) of 357 patients in the study at the first surgical intervention. p-PHPT developed in 14 patients. As a result of additional imaging methods applied to these patients, secondary surgical intervention was applied to 11 patients, and surgical cure was provided in 10 of them (90.1\%). Four patients re- mained persistent (1.1\%). In the follow-up of the patients, 4 patients (1.1\%) developed r-PHPT, and the total cure rate of the series was $97.8 \%$. When compared with the literature, the surgical cure rate was sufficient and satisfactory both after the first and secondary intervention.

Persistent or recurrent PHPT was seen around 30\% in the 90 s, but today, it is still seen between $2.5 \%$ and $5 \%$ despite all the developments in imaging and technology. ${ }^{[28]}$

The most common reason for these cases is an orthotopic or ectopic secondary hyperfunctioning parathyroid tissue that cannot be seen in the first surgery, recurrent parathyroid adenoma due to insufficient resection, or failure to remove all of the pathological glands in multiple gland diseases. ${ }^{[29]}$ Rarely, parathyromatosis due to capsule rupture of the removed gland may also be an etiological factor. ${ }^{[30]}$ Although it is rarely seen, hyperparathyroidism can be seen due to the implanted parathyroid tissue after total parathyroidectomy and autoimplantation or due to remnant parathyroid tissue after subtotal parathyroidectomy. Although this condition is generally seen in secondary hyperparathyroidism patients, a case of r-PHPT due to autoimplanted parathyroid tissue has also been reported in the literature. ${ }^{[31]}$ 
Obesity, patients with $>70$ years of age, surgeon's inexperience, low case volume of the center, ASA 3 patient, suspicious imaging methods, the first parathyroid gland pathology being multiglandular (multiglandular disease $>$ double adenoma $>$ single adenoma), and surgical strategy choice are risk factors for persistent and recurrent PHPT. ${ }^{[30]}$

In addition to risk factors such as ectopic parathyroid gland, insufficient resection, and multiple gland disease, the surgical experience of the team in the first operation is also an important factor in the development of recurrent or persistent hyperparathyroidism. ${ }^{[32]}$ Cure was achieved in $10(90.9 \%)$ of our 11 patients who were operated for the second time due to persistent disease. Of these, two were ectopic, five were orthotopic, seven had second adenoma (70\%), and three patients had PT adenoma (two ectopic and one orthotopic) that was not removed in the first surgery.

Although the success rate in secondary interventions for p-PHPT was reported to be lower than $65-75 \%$ in the previous studies, it has been reported that over $90 \%$ success rate can be achieved with developed imaging methods in experienced centers and intraoperative PTH tests. ${ }^{[24]}$

In the first pre-operative imaging, the second adenoma in seven double adenoma patients and in two patients with a single adenoma, the pathological gland was not visualized in the first scintigraphic imaging. In particular, multinodular goiter, posterior or intrathyroidal lesions of the thyroid, ectopic localizations, small glands and multiple gland disease, and obesity decrease sensitivity in scintigraphy. ${ }^{[33]}$ In our series, seven second adenomas could be visualized in the secondary imaging performed after removal of the first adenoma, and they were operated with limited surgery. In addition, parathyroid adenoma became visible after the removal of follicular thyroid cancer, which was the cause of false positivity in a patient with a single adenoma. Especially in patients with $\mathrm{p}$-PHPT, pre-operative additional imaging methods can be used to detect the majority of the pathological glands and successful results can be obtained with FPS. Negative imaging in the first intervention in PHPT is not a contraindication for FPS or UNE, but negative or indeterminate imaging can be considered as a relative contraindication in reoperative surgery. ${ }^{[16]}$

In patients with persistent and recurrent hyperparathyroidism, with asymptomatic or mild symptoms, in patients with negative imaging, follow-up can be considered, with the benefit-harm ratio and the risks of redo surgery taking into account. $^{[30]}$

Although recurrent hyperparathyroidism is usually seen in PHPT patients with multiple gland disease with a family history, it may be caused by regrowth of resected parathyroid tissue or hyperfunction of autotransplanted parathyroid tissue. ${ }^{[30]}$ The development of a second adenoma during the follow-ups in lesions that are normal in the first operation is a rare condition and can be seen in patients with a history of neck radiation..$^{[34]}$ Mainali et al. ${ }^{[35]}$ reported that the rate of r-PHPT was higher in patients who underwent secondary parathyroidectomy compared to those who underwent primary surgery. In addition, Mazotas et al. ${ }^{[36]}$ found that r-PHPT was higher in patients with double adenoma than patients with single gland and multiglandular disease, suggesting that this may be related to double adenomas being unrecognized multiglandular disease.

The main limitations of the study are that it is retrospective, there are no follow-up data for all patients, and the contribution of additional methods such as intraoperative PTH measurement was not evaluated.

As a result, the only definitive treatment for PHPT is surgery. High surgical cure can be achieved with FPS, UNE, or BNE by pre-operative evaluation and appropriate surgical planning. However, despite high cure rates, p-PHPT may develop, especially due to double adenoma or ectopic location. Patients with p-PHPT can be evaluated with reimaging methods and with appropriate surgical planning, a high cure rate can be obtained in secondary surgery and this can increase the total surgical cure rate. Recurrence rate is rare.

\section{Disclosures}

Ethics Committee Approval: The Sisli Hamidiye Etfal Teaching and Research Hospital Clinical Research Ethics Committee granted approval for this study (date: 30.03.2021, number: 1822).

Peer-review: Externally peer-reviewed.

Conflict of Interest: None declared.

Financial Disclosure: The authors declare that this study received no financial support.

Authorship Contributions: Concept - N.A., I.E.A., A.I., M.U.; Design - N.A.; Supervision - A.I., M.U.; Materials - N.A., M.T.U., S.G.Y., R.S.E.; Data collection \&/or processing - M.T.U., N.A.; Analysis and/ or interpretation - M.U., M.T.U.; Literature search - M.T.U.; Writing - M.T.U.; Critical review - M.U.

\section{References}

1. Walker MD, Bilezikian JP. Primary hyperparathyroidism: recent advances. Curr Opin Rheumatol 2018;30:427-39. [CrossRef]

2. Madkhali T, Alhefdhi A, Chen H, Elfenbein D. Primary hyperparathyroidism. Ulus Cerrahi Derg 2016;32:58-66. [CrossRef]

3. Bilezikian JP, Brandi ML, Eastell R, Silverberg SJ, Udelsman R, Marcocci $C$, et al. Guidelines for the management of asymptomatic primary hyperparathyroidism: summary statement from the Fourth International Workshop. J Clin Endocrinol Metab 2014;99:3561-9. [CrossRef]

4. Wilhelm SM, Wang TS, Ruan DT, Lee JA, Asa SL, Duh QY, et al. The American Association of Endocrine Surgeons Guidelines for definitive management of primary hyperparathyroidism. JAMA Surg 2016;151:959-68. [CrossRef]

5. Laird AM, Libutti SK. Minimally invasive parathyroidectomy versus bilateral neck exploration for primary hyperparathyroidism. Surg Oncol Clin N Am 2016;25:103-18. [CrossRef] 
6. Singh Ospina NM, Rodriguez-Gutierrez $R$, Maraka $S$, Espinosa de Ycaza AE, Jasim S, Castaneda-Guarderas A, et al. Outcomes of parathyroidectomy in patients with primary hyperparathyroidism: a systematic review and meta-analysis. World J Surg 2016;40:2359-77. [CrossRef]

7. Cheatem DM, Surgeon C. Tecnique of parathyroidectomy. In: Clark OH, Duh QY, Kebebew E, Gosnell JE, Shen WT, editors. Textbook of Endocrine Surgery. $3^{\text {rd }}$ ed. Jeypee Brothers Medical Publishers; 2016. p.747-56. [CrossRef]

8. Uludag M. Preoperative localization studies in primary hyperparathyroidism. Sisli Etfal Hastan Tip Bul 2017;53:7-15.

9. Westerdahl J, Bergenfelz A. Unilateral versus bilateral neck exploration for primary hyperparathyroidism: five-year follow-up of a randomized controlled trial. Ann Surg 2007;246:976-80. [CrossRef]

10. Tibblin S, Bondeson AG, Ljungberg O. Unilateral parathyroidectomy in hyperparathyroidism due to single adenoma. Ann Surg 1982;195:245-52. [CrossRef]

11. Irvin GL $3^{\text {rd }}$, Carneiro DM, Solorzano CC. Progress in the operative management of sporadic primary hyperparathyroidism over 34 years. Ann Surg 2004;239:704-8. [CrossRef]

12. Allendorf J, DiGorgi M, Spanknebel K, Inabnet W, Chabot J, Logerfo $P .1112$ consecutive bilateral neck explorations for primary hyperparathyroidism. World J Surg 2007;31:2075-80. [CrossRef]

13. Shen W, Düren M, Morita E, Higgins C, Duh QY, Siperstein AE, et al. Reoperation for persistent or recurrent primary hyperparathyroidism. Arch Surg 1996;131:861-7. [CrossRef]

14. Mariette C, Pellissier L, Combemale F, Quievreux JL, Carnaille B, Proye $C$. Reoperation for persistent or recurrent primary hyperparathyroidism. Langenbecks Arch Surg 1998;383:174-9. [CrossRef]

15. Caron NR, Sturgeon $C$, Clark OH. Persistent and recurrent hyperparathyroidism. Curr Treat Options Oncol 2004;5:335-45. [CrossRef]

16. Udelsman R. Approach to the patient with persistent or recurrent primary hyperparathyroidism. J Clin Endocrinol Metab 2011;96:2950-8. [CrossRef]

17. Udelsman R. Six hundred fifty-six consecutive explorations for primary hyperparathyroidism. Ann Surg 2002;235:665-70. [CrossRef]

18. Chapuis Y, Fulla Y, Bonnichon P, Tarla E, Abboud B, Pitre J, et al. Values of ultrasonography, sestamibi scintigraphy, and intraoperative measurement of 1-84 PTH for unilateral neck exploration of primary hyperparathyroidism. World J Surg 1996;20:835-9.

19. Civelek AC, Ozalp E, Donovan P, Udelsman R. Prospective evaluation of delayed technetium-99m sestamibi SPECT scintigraphy for preoperative localization of primary hyperparathyroidism. Surgery 2002;131:149-57. [CrossRef]

20. Alhefdhi A, Schneider DF, Sippel R, Chen H. Recurrent and persistence primary hyperparathyroidism occurs more frequently in patients with double adenomas. J Surg Res 2014;190:198-202.

21. Kartal A, Citgez B, Oden S, Yetkin SG, Mihmanlı M, Aygun N, et al. Risk factors in the occurance of persistent primary hyperparathyroidism. Sisli Etfal Hastan Tip Bul 2014;48:223-6. [CrossRef]
22. Tezelman S, Shen W, Siperstein AE, Duh QY, Clark OH. Persistent or recurrent hyperparathyroidism in patients with double adenomas. Surgery 1995;118:1115-22. [CrossRef]

23. Bagul A, Patel HP, Chadwick D, Harrison BJ, Balasubramanian SP. Primary hyperparathyroidism: an analysis of failure of parathyroidectomy. World J Surg 2014;38:534-41. [CrossRef]

24. Karakas E, Müller HH, Schlosshauer T, Rothmund M, Bartsch DK. Reoperations for primary hyperparathyroidism-improvement of outcome over two decades. Langenbecks Arch Surg 2013;398:99106. [CrossRef]

25. NIH conference. Diagnosis and management of asymptomatic primary hyperparathyroidism: consensus development conference statement. Ann Intern Med 1991;114:593-7. [CrossRef]

26. Mihai R, Barczynski M, lacobone M, Sitges-Serra A. Surgical strategy for sporadic primary hyperparathyroidism an evidence-based approach to surgical strategy, patient selection, surgical access, and reoperations. Langenbecks Arch Surg 2009;394:785-98.

27. Egan RJ, Scott-Coombes DM. The surgical management of sporadic primary hyperparathyroidism. Best Pract Res Clin Endocrinol Metab 2018;32:847-59. [CrossRef]

28. Venkat R, Kouniavsky G, Tufano RP, Schneider EB, Dackiw AP, Zeiger MA. Long-term outcome in patients with primary hyperparathyroidism who underwent minimally invasive parathyroidectomy. World J Surg 2012;36:55-60. [CrossRef]

29. Yozawitz J, Zarnegar R, Fahey TJ. Recurrent primary hyperparathyroidism after autotransplantation of an excised parathyroid adenoma. Clin Surg 2017;2:1450.

30. Guerin C, Paladino NC, Lowery A, Castinetti F, Taieb D, Sebag F. Persistent and recurrent hyperparathyroidism. Updates Surg 2017;69:161-9. [CrossRef]

31. Chou FF, Lee $\mathrm{CH}$, Chen HY, Chen JB, Hsu KT, Sheen-Chen SM. Persistent and recurrent hyperparathyroidism after total parathyroidectomy with autotransplantation. Ann Surg 2002;235:99104. [CrossRef]

32. Yeh MW, Wiseman JE, Chu SD, Ituarte PH, Liu IL, Young KL, et al. Population-level predictors of persistent hyperparathyroidism. Surgery 2011;150:1113-9. [CrossRef]

33. Aygün N, İşgör $A$, Uludağ $M$. The effectiveness of preoperative ultrasonography and scintigraphy in the pathological gland localization in primary hyperparathyroidism patients. Sisli Etfal Hastan Tip Bul 2019;53:379-84.

34. Henry JF. Reoperation for primary hyperparathyroidism: tips and tricks. Langenbecks Arch Surg 2010;395:103-9. [CrossRef]

35. Mainali B, Lindeman B, Chen $\mathrm{H}$. Re-operative parathyroidectomy in patients with mild primary hyperparathyroidism. J Surg Res 2020;255:130-4. [CrossRef]

36. Mazotas IG, Yen TWF, Doffek K, Shaker JL, Carr AA, Evans DB, et al. Persistent/Recurrent Primary Hyperparathyroidism: Does the Number of Abnormal Glands Play a Role? J Surg Res 2020;246:335-41. [CrossRef] 